\title{
1960-1980 Arası Değişen Doğa Algısı ve Sanatta Doğaya Yöneliş
}

Damla OČUZ *

Özet

1960 sonrası dünyada gelişen toplumsal ve çevresel hareketlerden etkilenen sanatçılar sadece doğaya öykünmemiş, onun yerine doğa-insan ilişkilerindeki problemlere kendi sanatsal dillerini kullanarak dikkat çekmek istemiş ve toplumu bilinçlendirmek yönünde davranmışlardır. Malzeme seçiminden, yarattıkları eylemlere kadar, bu sanatçılar sanatlarının diliyle yaşadıkları dönemin yerleşik düşünce kalıplarına karşı koymuşlardır. Buradan hareketle sınırları 1960 ve 1980 yılları arası dönem olarak belirlenen bu metinde, değişen toplumsal değerler ve sanatsal pratikler kapsamında sanat ve doğa ilişkisine değinilmiştir. Bu ilişki içerisinde, önceki dönemlerde yaşamış sanatçılardan farklı olarak, dönemin sanatçılarının doğayı nasıl anlamlandırdıkları, oluşturdukları eserler üzerinden değerlendirilmiştir.

Anahtar Sözcükler: Sanat, Sanatçı, Yeryüzü, Doğa, Manzara, Gelip Geçicilik, Çevresel Sorunlar.

\section{The Changing Perception of Nature between 1960-1980 and the Tendency of Arts Towards Nature}

\section{Abstract}

The artists, who were affected by the social and environmental movements that emerged in the world after 1960, not only imitated the nature, but also wanted to draw attention to problems in nature-human relationship by using their own artistic languages and acted towards raising the awareness of society. From the choice of materials to the actions they created, these artists resisted the settled mentality of their period with their artistic language. Thus, in this paper, the relationship of art and nature is considered within the context of changing social values and art practices in the period between 1960 and 1980. Within this relationship, the artists of the period are evaluated over how they gave meaning to the nature with the works they created so that they differed from the artists of the previous eras.

Keywords: Art, Artist, Earth, Nature, Landscape, Ephemeral, Environmental Problems. 


\section{Giriş}

\section{0 Öncesi Sanat ve Doğa i lişskisine Genel Bir Bakış}

Doğa ile insanoğlu arasındaki karşılıklı etkileşim kaçınılmazdır. Bu etkileşim esnasında doğayı kendi yoğunluğu içerisinden çıkartıp görünür kılan ve bir düzene oturtan da insanoğlunun ona bakışıdır. İnsanoğlu doğanın yasalarını öğrenerek doğa üzerindeki denetimini arttırır ve onu türlü biçimlere sokar. Sanatçı içinse doğa her zaman merak uyandırmış ve ilham kaynağı olmuş, aralarındaki büyülü ilişki dünyanın her yerinde birçok değerli ve olağanüstü yapitlarla kendini sunmuştur. Bu anlamda sanat tarihini, "insanın doğayla olan ilişkilerinin üretiminin tarihi olarak tanımlayabiliriz." (Bourriaud, 2005: 46).

Sanatçı her çağda yaşadığı toplumu biçimlendiren, yansıtan ve birlikte yaşadığı insanlarla sanatı yoluyla diyalog kuran kişidir. İster tanrıya yaklaşmak için isterse egemen olmak veya meydan okumak için olsun, sanatçının amacı her zaman hayatının içeriğini kalıcı bir evrene dönüştürebilmek olmuştur (Worringer, 1995: 11). Sanatçı sanatsal etkinliğini gerçekleştirirken doğayı duygularının süzgecinden geçirir, değiştirir ve böylece onu yeni bir varlık biçimine dönüştürür. Oluşturduğu bu evrende sanatçı biçimsel veya içeriksel tüm göndermelerini doğa üzerinden, doğaya karşı gerçekleştirir. Ancak sanat yapıtında doğadaki şeyler değil, onların aralarındaki ilişkiler önemlidir. Böylece doğanın sonsuz sayıdaki ilişkilerinin aktarıldığı sanat yapıtı, doğanın yanında ona eşdeğerli olarak bulunan ama doğadan bağımsız bir organizma olarak var olan bir evrendir (Worringer, 1995: 11).

Sanatsal etkinlik de tüm diğer insan etkinlikleri gibi çağlara ve toplumsal içeriklere göre evrilir. Insanların doğaya bakışındaki ayrılıklar, dönemin egemen sanat anlayışının doğayı algılayışındaki ayrılıklara denk gelir. Bu çerçevede sanatçının doğaya bakışı ve ondan aldıkları da değişikliğe uğramaktadır. Sanat icra eden insan olarak sanatçı ile bu insanın elinde bir malzeme niteliği taşıyan doğa arasındaki ilişkide en temel varsayım sanatçının gözleriyle gördüğü dış dünyayı temsil ettiğidir. Bu dış dünya genel olarak doğa kavramına karşıık gelir. Eğer ki sanatçının yegâne hedefi bu dış dünya ya da diğer bir deyişle doğa ile kurduğu öznel ilişki ise o zaman farklı tarihsel dönemlerde yaşamış her bir sanatçının çalışmalarında farklı doğa tasarımları olduğu söylenebilir.

Sanatçı doğa biçimini sanat biçimine dönüştürürken kimi zaman, doğanın birebir taklidine dayalı gerçekçi bir çözümleme tercih etmiş, kimi zaman da duyguların daha yoğun işlendiği ve hatta daha gerçeküstücü ifadeler ortaya çıkarmıştır. Uzun bir zaman boyunca sanat bir tasvir aracı olarak görülmüş, doğa da bu tasvirin alt yapısını oluşturacak bir alan olarak algılanmıştır (Read, 2004: 56). Herbert Read'e göre (2004: 57) “Bizim yani modern insanın şimdi sanat adını verdiği şeye eski insanlar hüner ve teknik beceri olarak bakmıştır. Dolayısıyla sanatı o dönemler için insan iradesinin canlı/cansız nesnelere dayatılması olarak görebiliriz.". Doğa ideal olanla eşleştirilene ve sanatın da bu ideali taklit etmesi gerektiği düşüncesine kadar birçok uygarlık sanatı hüner ve teknik beceri olarak algılamış ve uygulamıştır.

Sanatın ideal doğanın taklidi olduğu düşüncesi 18. yüzyıl ortalarına kadar varlık bulur. Ama daha sonra bu doğa kavrayışındaki idealizm gözden düşer ve bilimin yükselişi doğa algısını da değiştirir. Doğa artık kuralsızıı̆̆, çeşitliliği ve tüm gerçekliği ile güzeldir. Ancak bakış açısındaki bilimsellik onun taklit edilebilirliğini önlemez. Ancak bu taklit bir idealin değil, bir gerçekliğin, şeylerin gözle görülen gerçekliğinin taklididir (Read, 2004: 57).

Constable'ın 'Saman Arabası' isimli eseri 1824'te Paris'te ilk sergilendiğinde olay yaratır (Resim 1). Bu çaıışma sanatçının doğa ile kurduğu ilişki bakımından devrim niteliğindedir ve yerleşik geleneksel sanat anlayışını savunan birçok çevreyi rahatsız eder. Constable, sanatçıların resimlerini yapmak için kendi hayal gücünü kullanmalarını öğreten sanat kültürüne, doğaya, doğanın bizzat kendini çizmeye yönelen kararı ile böylece karşı çıkıyordu (Thornes, 1999: 57). Daha sonra Manet'nin Olympia'sı gibi çalışmalar ve genel olarak İzlenimcilikle beraber 0 zamana kadarki doğa algısında bir kopuş meydana gelir. Renk bilimi ve daha sonra ilkel halkların sanat anlayışının 
yayılması ile ortaya çıkan farklılıklarla beraber bu dönemde bilginin sürekli yaygınlaşması, sanatçıyı ve dolayısıyla sanatı da değiş̧tirir (Read, 2004: 57). Bu evrede Cezanne önemli bir duruş sergiler. Doğaya olan analitik yaklaşımı ve deneyselliği teknik bir dil olarak benimsemesi itibariyle Cezanne dönemin sanatçısının bilimsellikten ne kadar etkilendiğinin kanıtıdır (Read, 2004: 57).

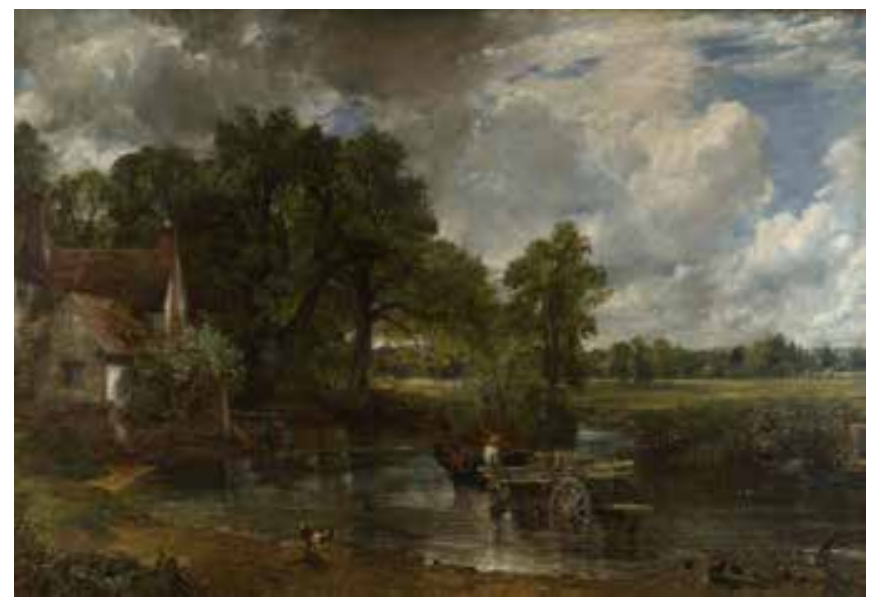

Resim 1. 'Saman Arabası', John Constable, 1821.

Önceki geleneğin tipik temsilcilerinden biri olan Reynolds, 'Seven Discourses in Art' (Sanatta Yedi Söylem) (Read 2004: 57'den) isimli yapıtında şöyle söyler: “...Sanatçı doğayı doğayla düzeltir, kusurlu halinin yerine kusursuzluğunu koyar. Şeylerin rastlantısal eksikliklerini, fazlalıklarını ve bozukluklarını şeylerin genel biçimlerinden ayırt edebilen gözleri sayesinde, daha kusursuz olan formların soyut kavramına ulaşır.". Reynolds'ın bu sözleri kendinden yüz yıl kadar önce yaşamış olan düşünür Francis Bacon'ın sözlerini anımsatır niteliktedir. Bacon da hedefsiz, sapkın ve amaçsız olarak tanımladığı doğayı insanın elinde işlenebilecek, düzenlenebilecek bir hammadde olarak görüyordu. Reynolds'a ve çağdaşlarına dönecek olursak, onların bahsettiği şey, bir güzellik ideası yaratmak uğruna doğayı sanatçının katı biçimciliğine mahkûm etmek kadar sanatçıyı da doğanın kontrolüne bırakmaktır (Read, 2004: 57). Modern sanatçının ölçütü ise güzelden çok gerçektir ve bu anlamda modern sanat doğa bilimleriyle yan yana ilerler.

Bilime duyulan genel ilgi doğrultusunda izlenimci- likten gerçeküstücülüğe kadar geçen dönemde, algı fizyolojisinden, psikoloji bilimine kadar birçok alandan etkilenen sanatçı doğaya analitik bir tavırla yaklaşır. 1900'lerin başlarından itibaren analitik kübizm ile beraber devam eden bilimsellik sentetik kübizmin ortaya çıkmasıyla beraber yerini sanatın kendi doğası kavramının yaygınlaşmasına bırakır. Juan Gris sanat yapıtının bir estetik gerçeklikten yola çıkması gerektiğini öne sürer (Read, 2004: 57). Bunun anlamı iki boyutlu düzlemin soyut kavram ve tasarımlarla düzenlenmesidir. Bu da sanat yapıtının temelinden doğayı olabildiğince temizlemekle mümkündür. 1900'lerden sonra bir süre doğadan tamamen kopmak gerekliliği savunulur. Örneğin Mondrian ve Maleviç'e göre sanatçının yaptığı işlerin doğa ile hiçbir ortak noktası olmamalıdır (Resim 2). Bu ve bundan sonra gelecek olan soyut sanat biçimleri en temel varsayımlarını sanatın doğaya bağımlı olduğu anlayışının reddedilmesi üzerine kurar. Herbert Read'e göre (2004: 57) bu sanatçılar "ne Reynolds gibi doğayı 'yansıtıyor', ne de izlenimciler gibi doğaya saygı duyuyorlardı; onların doğayla işi yoktu. Bazıları doğanın temel niteliklerinin temsillerini üretmeyi denediler - yani, evrenin kendisinin fiziksel yapısına içkin olan düzenin yasalarını; ama diğerleri onun verili niceliğinden bile bağımsız olduklarını, bütünüyle farklı bir gerçeklik üretebileceklerini öne sürdüler”. Temsili olmaktan uzak durmaya özel bir çaba harcayan bu tavırda, çizgilerin biçimlerin ve renklerin belli bir düzenleme ile oluşturdukları ilişki esastı ve bu düşünce biçimi kendini 20. yüzyılın ortalarına kadar hissettirdi.

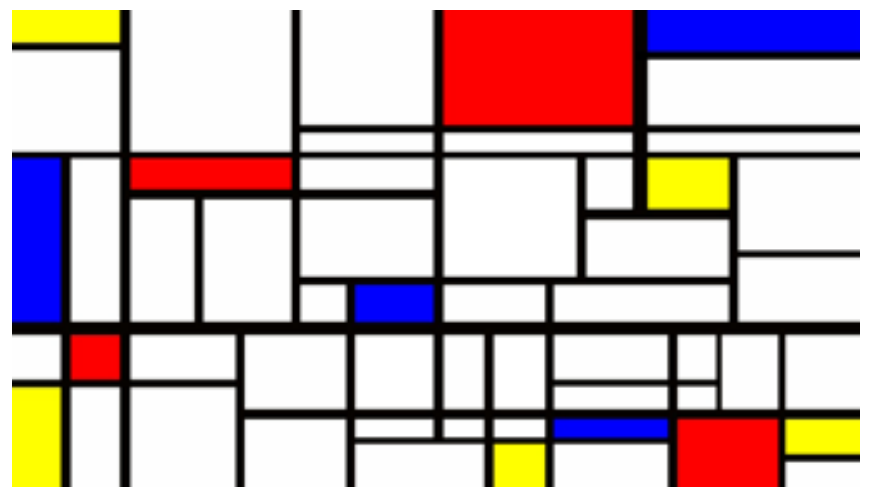

Resim 2. 'Kırmızı, Sarı ve Mavili Kompozisyon',

Piet Mondrian, 1921. 


\section{Bir Sergi Mekanı Olarak Yeryüzü}

20. yüzyıl, iletişim ağlarının yaygınlaşmasıyla sınırları aşan bilimsel ve teknolojik gelişmelere damgasını vuran bir çă̆dır. Ne var ki modernleşmenin arka planında yatan aydınlanma, akla duyduğu sonsuz güvenden dolayı bilim aracılığı ile insanlığın her sorununu çözmeyi vaat etmiş olsa da, her iki büyük savaş bu modernist projenin başarısızlığını göstermiş, akla, bilime ve uygarlığa güvensizliği getirmiştir. Bu durumun meydana getirdiği sosyal ve ruhsal problemler karşısında sanatçı da doğaya karşı tavır değiştirip, izleyicinin göz zevkine hitap edecek eserler üretmekten çok, düşünce üretip, içinde yaşadığı çağın problemlerine dikkat çekmek ve sorgulamak istemiştir. Sanatçıların sosyal meselelerle bu denli ilgilenmeleri, eserlerinin biçimlenişine de yansımıştır.

Özellikle 1960 sonrası doğa daha büyük bir yoğunlukla ele alındı, çevre sorunları sanatın yeni alanlarının doğmasına yol açtı. Sanat, bir tür farkındalık çağrısına dönüştü ve bu dönemde sanatçılar da doğa ve insan uyumunu sağlayacak yeni yollar aramaya başladı. Bundan sonra yeryüzü sınırsız malzemeye sahip ve uçsuz bucaksız bir sergi mekânı olarak sanatçıların dikkatini çekti. Yeryüzüne yönelimin altında yatan sebeplerden, kentsel ve çevresel sorunların yanında, dönemin sanat piyasası, galeri ve müzelere duyulan tepki de etkili oldu. Böylece bu sanatçılar dış mekânla karşı karşıya geldi ve yapıtlarını da bu doğal çevrede gerçekleştirdi. Artık sanatçı için yapıtının da yaşam gibi gelip geçici ve zamanla değişebilir olması önem kazanmaya başladı. Sanata farklı bir şekilde yaklaşan bu sanatçılardan kimi doğa görüntülerine yeni unsurlar katarak ona dikkat çekmeyi, kimi doğal malzemeleri kullanarak yeni yapıtlar ortaya çıkarmayı, kimisi de salt doğayı koruma amacıyla yeniden düzenlemeyi amaçladılar.

1961'de Manzoni, dünyayı bir kaideye koyduğunda onu hem dışsal bir varlık gibi hissetmemizi ve ona dışarıdan bakmamızı sağlamış hem de dünyanın, diğer bir deyişle yeryüzünün kendisinin de bir sanat yapıtı olabileceği düşüncesini akıllara getirmiştir (Resim 3-4). Bu, bir anlamda, boşluğun, atmosferin, dışarının da sanata dâhil oluşunun ilk örneklerindendir. Bu, ilk elde, beyaz küpün dışına çıkma ihtiyacının, onun kapsayıcı ve kapatıcı özelliklerine duyulan tepkinin yansımasıdır. Dolayısıyla kendini sınırları önceden belirlenmiş bir bağlamdan, Smithson'ın (Lipke, 1969'dan) deyişiyle “hapishaneden kurtarmak"tır.

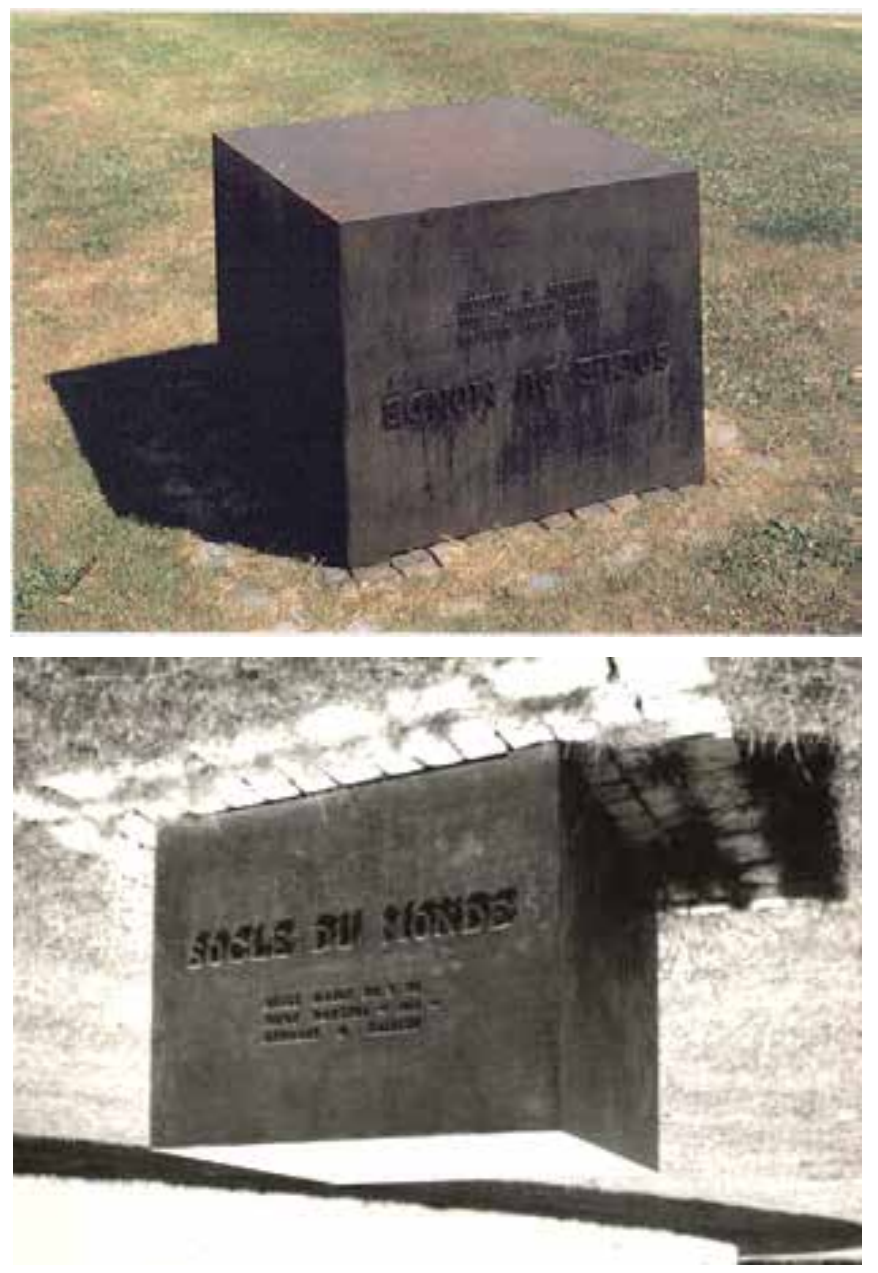

Resim 3-4: ‘Dünyanın Kaidesi’, Piero Manzoni, 1961.

Robert Smithson (Lipke, 1969'dan) “Galeri duvarları dört tarafı kapalı ve sanatı kendi içine hapseden mekânlardır. Sanat eseri buralarda bir tür değerlilik ölçütüne girer ve yapıt, galeri duvarlarını süsleyen dekoratif bir niteliğe bürünür ve hapsolur." demektedir. Robert Smithson, kendisinin 'tasarlanmış alanlar' üzerine değinmekle ilgilenmediğini söylemiştir. Görüntünün bir dikdörtgen içinde toplanması boşluğun göz ardı edilmesine ve hat- 
ta yok edilmesine neden olur (Lipke, 1969). Smithson'ın boşluktan kastettiği ise dışarıdaki atmosferdir.

Benzer kaygılara sahip olan Michael Heizer de, galerilerde sergilenen eserlerin boşluktan yoksun olduklarını söyler. Dışarı çıkma sebebini boşluksuz heykel yaratmayı terk etmek istemesi olarak açıklar. Boşluksuz heykel yapmama pratiğini Heizer heykel olmayan veya tersine dönmüş heykel olarak betimler. Buradan hareketle 1969 yılında Nevada çölünde 'Çift Negatif' isimli işini gerçekleştirmiştir. Bu işi birbirine karşıt duran ve boşluğu da içeren iki derin yarıktan oluşmaktadır (Kimmelman, 1992) (Resim 5).

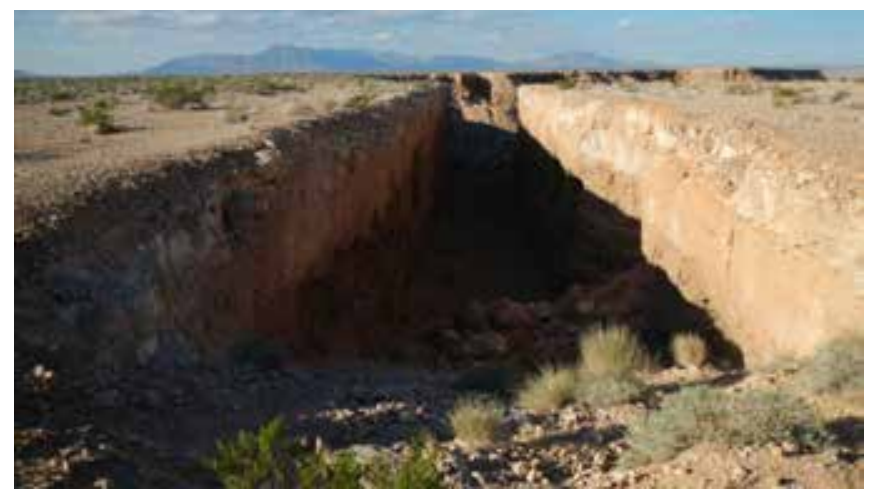

Resim 5. 'Çift Negatif’, Michael Heizer, 1969.

Kavramsal olarak insanlığa ulaşmak isteğinde olmalarına karşın bu çalışmaların uzak mekânlarda özellikle de çöller de gerçekleştirilmeleri bir çelişki olarak algılanabilir. Ancak uzaklara kaçış, birçok dönem, uygarlığın baskılarından ve teknolojinin bireyin kişiliğini boğarak, onu isimsizleştiren unsurlarından kurtulmaya çalışan sanatçının seçtiği yollardan biridir. Çöl, el değmemiş ve sonsuz olanaklar veren bir mekândır. İnsansız çevrede oluşturulan bu çalışmalar, insanın evrenin sonsuzluğu karşısındaki aciz durumunun simgesi gibidir. Ayrıca ilk arazi yönelimli çalışmaların Amerika kıtasında ortaya çıkması bir rastlantı değildir. Aksine kıtanın geniş alanlara ve uçsuz bucaksız çöllere sahip olması, bu sanatçıların mekânsal olarak hareketliliğini de kolaylaştırmıştır.

\section{Gelip Geçicilik: Yaşam Döngüsüne Katılan Eser}

Doğa çoğu zaman insanlık ile tanrısallık arasında bir bağ kurucu ya da seyirlik bir peyzaj olarak algılanır. Ancak 1960’lar doğa peyzajına fiziksel bir gerçeklik olarak yaklaşılan ve onunla doğrudan ilişki kurulan yıllardır. Bundan böyle doğanın bir süreç olarak işleyişine duyulan hayranlık, sanatçıların yapıtlarına da yön verecektir. Zamanın sanatta bir öğe haline gelmesiyle, sanat yapıtı da artık doğanın bir parçası olur ve doğada, doğayla birlikte yaşayan bir organizmadır.

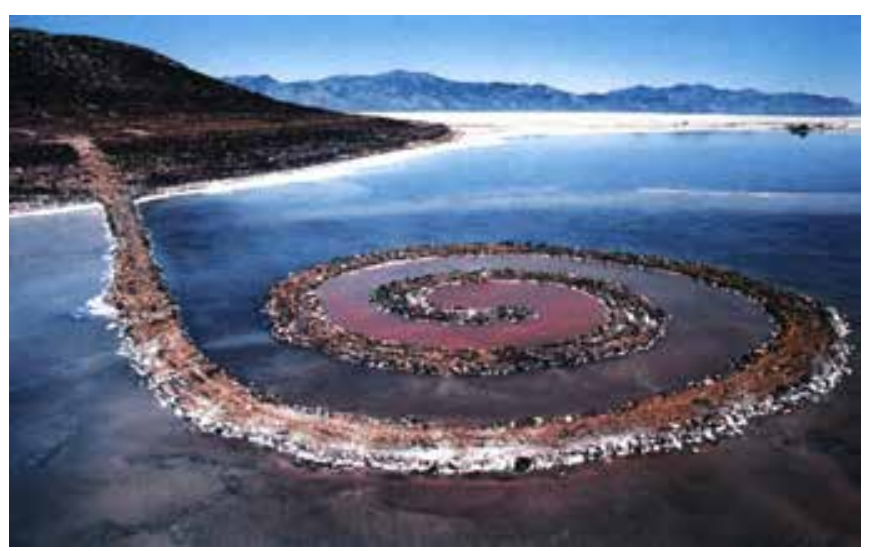

Resim 6. 'Spiral Dalgakıran’, Robert Smithson, 1970.

R. Smithson'a göre doğa (Yılmaz, 2006: 239'dan), içinde sürekli aşınıp taşınma sürecini barındıran bir diyalektiğe sahiptir. Doğaya saygısını, ona sahip çıkmayı önererek pekiştiren bir sanatçıdır Smithson. Bu saygı, doğanın, üzerine atılan her imzayı alıp kendi bünyesine, doğal sürecine katmasına duyulan bir saygıdır. Utah Tuz Gölü’nde gerçekleştirdiği ‘Sarmal Dalgakıran'da insanoğlunun doğada kurduğu ve kuracağı her türlü yapının doğanın işleyişine katılması gerekliliğini, kullandığı doğal malzemelerle anlatmak istemiştir (Resim 6). Dalgakıran siyah bazalt kayalardan oluşur ve önceleri sığ bir yüzeyde konumlanırken, gölün yükselmesiyle suların derinliklerinde kaybolur. Daha sonra göl tekrar çekildiğinde bembeyaz bir dalgakıran yüzeye çıkmıştır. Kurduğu yapının, doğal sürece katılmasının ve doğanın kendisiyle başa çıkabilmesinin gurur verici olduğunu belirten sanatçı; ölümünden sonra işinin restore edilmesine, dile getirdiği söylemleriyle de engel olmuştur (Sanford, 2004). Sarmal dalgakıran, doğanın, kendisine müdahalesi ve bu sürecin izlenebilir olması bakımından önem taşımaktadır.

Tavrını her zaman doğadan yana koyan başka bir sa- 
natçı J. Beuys'dur. Birer ayine dönüştürdügüü performanslarında, sanatın bir süreç olduğu düşüncesini yansıtmış, biyolojiden botaniğe, tarihten felsefeye uzanan ilgi alanlarından beslediği derslerini ve konferanslarını da birer sanat eylemi olarak düşünmüş ve yaşamıştır (Antmen, 2008: 206-207). J. Beuys, “dünyanın durumu insanlığın suçudur ve bütün bunlara ben de dâhilim. Fakat bilinçteki tembelliğin üstesinden gelmeye çalışıyorum." (Turhanlı, 2002: 9'dan) diyerek, doğa-uygarlık çıkmazını, modern toplumun çaresizliğini ifade eden sanatçılardan biri olmuştur. Meydana getirdiği tüm çalışmalarında, doğadaki ve insan yaşamındaki sürekliliği, değişimi ve yenilenmeyi, durağanlığa karşı koyuşu ifade eden Beuys şöyle devam eder (Turhanlı, 2002: 9'dan): “Heykellerimin doğası kesin ve bitmiş değildir. Birçoğunda işlemler sürmektedir; kimyasal reaksiyonlar, mayalanmalar, renk değişiklikleri, çürüme, kuruma. Her şey bir değişim durumundadır.".

Bu sanatçılar için insanın doğada kurduğu ve kuracağı her türlü yapının, doğanın işleyişine katılması gerekliliği söz konusudur ve inkâr, süreklilik, çürüme gibi kavramlar sanatın sözlüğüne girmiştir. Dışarıya çıkmakla asıında hâkim modernist ideolojiyi ve Greenberg'in (1939) “en iyi sanat onun formel özelliklerinde toplanandır" düşüncesini de reddetmiş ve sanat dünyası ile gerçek dünya arasında iletişim kurmaya çalışmışlardır. Dikkat edilmesi gereken, bu sanatçıların doğayı betimlemedikleri, doğayla doğrudan, temsilsiz bir ilişki kurduklarıdır. Onu yalnızca basit bir sanat yapıtı olarak algılamadıkları gibi, insanın doğal çevreyle bütünleşmesini de tetiklemişlerdir. Varlığına kuşku ve nefretle baktıkları kentin inşa etme ve yıkma eylemine, zamana karşı kayıtsız olan insana tepki göstermişlerdir.

Sokak gösterileri, ses enstalâsyonları ve performanslar gibi deneysel etkinliklerle sanat, 60'lı yılların kaynayan toplumsal ortamında gençliğin yıkıcı ruh halinin bir ifadesine dönüştü (Antmen, 2008: 205). Yeni oluşumlar pek çok sanatçı üzerinde özgür etkiler yarattı. Sanatla hayat arasındaki sınırları eritmek amacıyla, geleneksel sanat nesnesinin dışlanması, kalıcılık yerine gelip geçiciliğin felsefi bir tavır olarak benimsenmesi ve bitmiş yapıt yerine süreçselliğin ve ‘an'ın önemsenmesi (Antmen, 2008:
205) söz konusuydu. Meydana getirdikleri çalışmalarda kullandıkları malzemelerin her gün kullanılabilir, doğal ve genel olması, sanatçıların plastik sanatların klasik malzemelerinden ve onun sınırlılıklarından kurtulup, deneysel bir tavır sergilemelerini sağladı. Böylece doğaya, tarihe ve çağdaş yaşama dair olan her şeyi, kimi zaman çalı çırpıyla, kimi zaman canlı varlıklarla kimi zaman da çer çöple ifade etmeye çalıştılar.

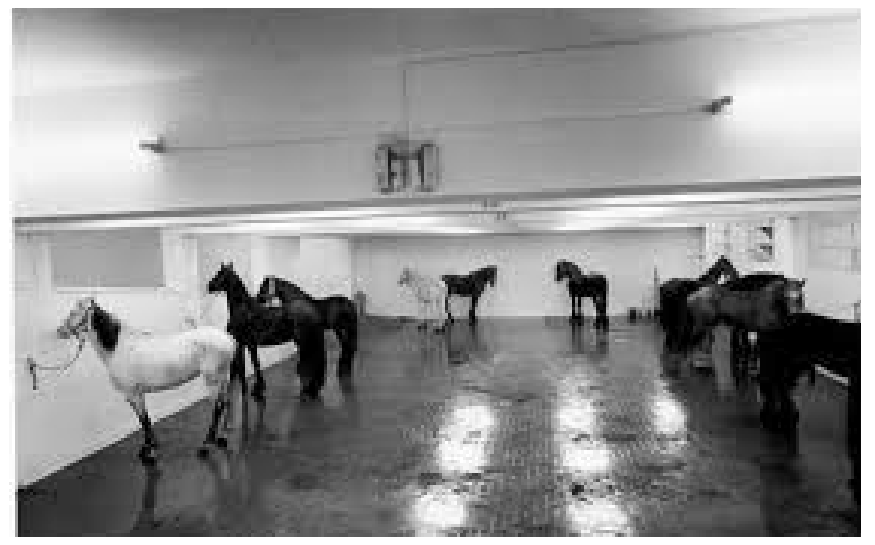

Resim 7. '11 At',Jannis Kounellis, 1969.

Doğanın ve doğa elemanlarının yalın görünümlerinden yararlanan bu sanatçılar, 20. yüzyıl sanatının yalnızca malzeme dağarcığını zenginleştirmekle kalmadı, farklı malzemelerin süreç içindeki değişimini izlenebilir ve gözlenebilir kılarak sanat deneyiminin sınırlarını da genişlettiler (Antmen, 2008: 213). "Hayvanlar, sebzeler ve mineraller sanat dünyasındaki yerini almaktadır" diyen Germano Celant (1992: 887-888), izleyiciyi bu tür malzemelerin geçirdiği fiziksel, kimyasal ya da biyolojik süreçleri izlemeye çağırmış, sanatçıları da gündelik malzemeyi dönüştüren bir simyacıya benzetmiştir.

Bu bağlamda en sansasyonel yapıtlardan biri, çalışmalarında olağan ve güncel malzemelere yer veren Kounellis tarafından, 1969 'da Roma'da bir galeride gerçekleştirilen '11 At' (Resim 7) enstalasyonudur. Sanatın alınıp satılan bir meta olmasına yönelik tepkinin uç noktada bir temsili olan bu eylem, on bir adet atın bir galeriye bağlanmasıyla gerçekleştirilmiştir (Antmen, 2008: 216).

Hayatın köklerine ulaşmayı hedef edinmiş birçok sa- 
natçı kullandıkları malzemeler ve yaptıkları tartışmalarla, sanatın nesnesini ortaya koymak yerine, sanatı ve hayatı çözümlemeyi tercih etmiş, böylece sanat farklı boyutlarda toplumla ilişki kurucu bir nitelik kazanmaya başlamıştır.

\section{Çevre Sorunları ve Sanat}

Alışılmadık bir düşünce sunan her sanat eseri asında huzur bozucu ve yıkıcıdır. Bu da sanatın siyasi yanını vurgular. Bu siyasi yapısı içinde sanat hem kendi içindeki hem de toplumdaki ön yargılara meydan okur ve dolayısıyla aktivist bir role (Spaid, 2002) bürünür. Sanatçılar da çoğu kez yarattıkları özel bir dille ve umulmadık yollarla toplum yapısına müdahale ederler.

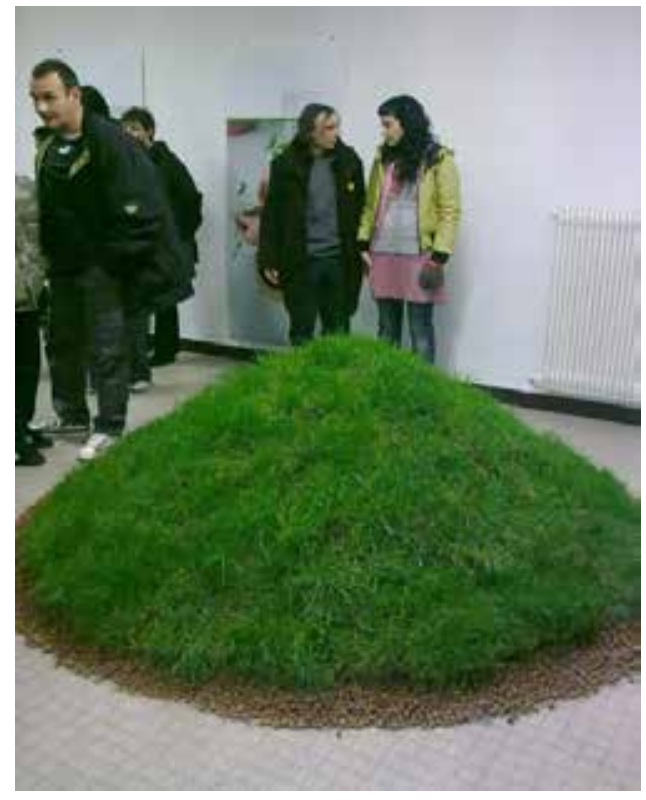

Resim 8. 'Çim Büyür', Hans Haacke, 1966-1969.

60'ların sonlarında birçok sanatçı minimal sanat fikri ile büyük anıtlar gerçekleştirirken Batı Almanya doğumlu sanatçı Hans Haacke ise dikkatini biyolojik sistemler ve doğa üzerine odaklamıştır. İnsan-çevre ilişkilerine ve sorunlarına her zaman iğneleyici bir siyasi dille yanıt arayan Haacke yolunu, politika, ekonomik sistemler, çevrebilim, endüstri ve diğer günlük hayat deneyim ve aktivitelerini barındıran, yaşam merkezli problemlere işaret edecek bir sanat inşa etmek üzerine kurmuştu. 1966'da Manhattan Galeri'de 1969 'da ise Cornell Üniversitesi'nin düzenlediği 'Toprak Sanatı' sergisinde kapalı bir alanda bir toprak kümesi içerisinde böcek ilacı kullanmadan çimen yetiştirmiştir. 'Çim Büyür' isimli çalışmada seyircinin ilgisini tipik bir olaya çekermiş gibi yaparken her bir izleyiciye akıl almaz derecede farklı deneyimler sunmuştur (Spaid, 2002) (Resim 8).

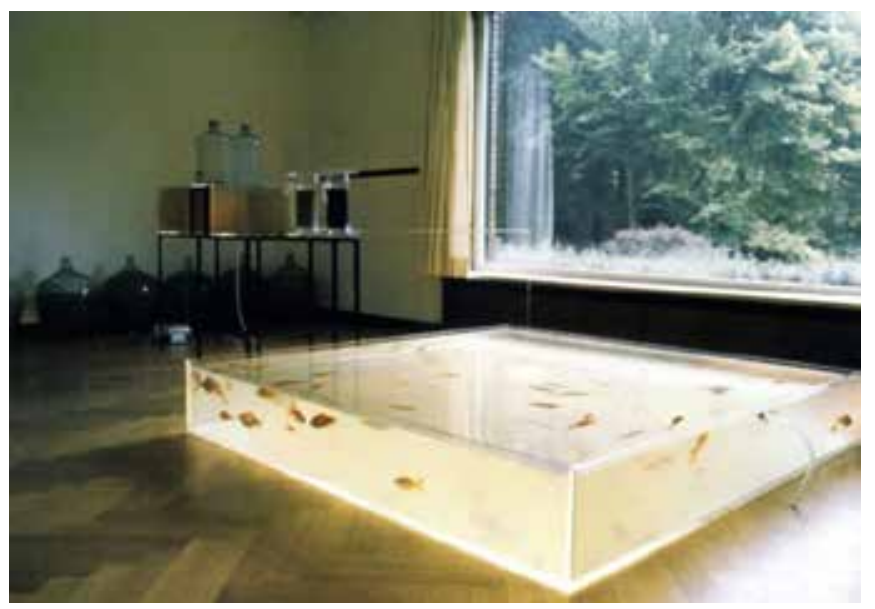

Resim 9. 'Ren Nehri Arındırma Projesi', Hans Haacke, 1972.

Ayrıca sanatçının Ren Nehri'nin kirliliği üzerine yap tığı ‘Ren Nehri Arındırma Projesi’ (Resim 9) ya da hayvanları bulundukları doğal ortamlardan ayırıp, onları hapsetmeye, evcilleştirmeye çalışan zihniyeti sorguladığı '10 Kaplumbağa Serbest Kalıyor' gibi çalışmaları, onun çevre sorunlarına ve toplumsal meselelere olan duyarlılığını gösterir (Yıldız, 2007: 33).

Beuys ise hem insan yaşamıyla doğa arasındaki bağlantıyı hem de radikal sosyal değişimleri betimlemede sanatın kapasitesini dile getirmek için gösteri sanatını kullanan ilk sanatçılardan biridir.

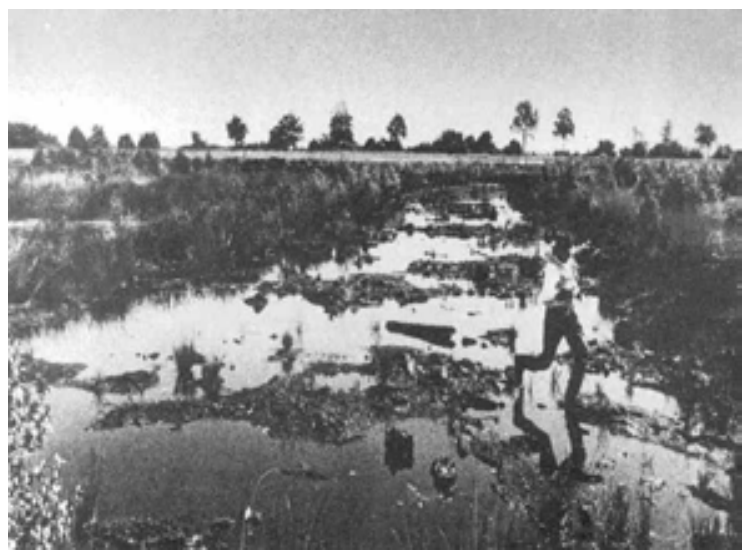

Resim 10. 'Bataklık Eylemi', Joseph Beuys, 1971. 


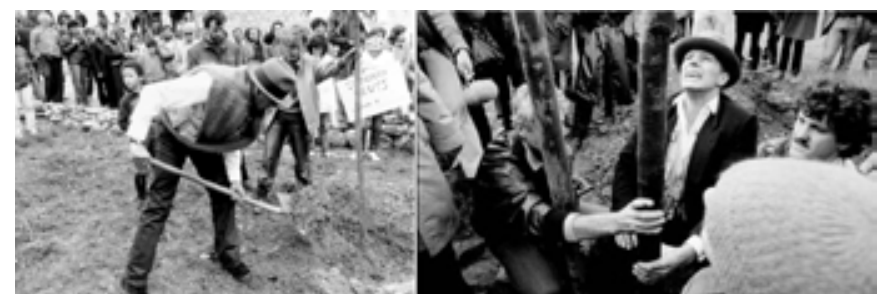

Resim 11. '7000 Meşe', Joseph Beuys, 1982.

Bataklıklara, Avrupa'nın en çok tehlike altındaki ekosistemine duyduğu kaygıyı göstermek için Beuys, 1971'de kendisinin bir bataklığa doğru koştuğu, çamurda yıkandığı ve nihayetinde bu bataklık çukuru boyunca yüzdüğü 'Bataklık Eylemi'ni gerçekleştirdi (Resim 10). Bataklıklar denizden kazanılmış toprak olarak bilinen deniz seviyesinin altında olan kara kütlesi haline gelme ve kuruma tehlikesi altındaydı. Aynı yıl Almanya'nın seri bir şekilde ormansızlaşmasıyla ilgili olarak Beuys ileri kentsel çevrebilimine duyulan intiyaca dikkat çekmek için Düsseldorf'ta bir orman eylemine öncülük etti (Spaid, 2002). Daha sonra 1974'te 'Ben Amerika’yı Seviyorum, Amerika da Beni' için bir kır kurdu ile kapanıp birkaç hafta geçirdi ve çevreyle ilgili kaygıları araştırdı. Amerikalı sığır yetiştiricilerinin çiftlik hayvanları için bir tehdit olarak gördükleri kır kurtlarına yönelik tavırlarını eleştirdiği bu performansında Beuys, Amerikan yerlilerinin kutsal saydıkları bu hayvanlar için kendi hayatlarını nasıl tehlikeye attıklarını sembolize etti (Spaid, 2002).

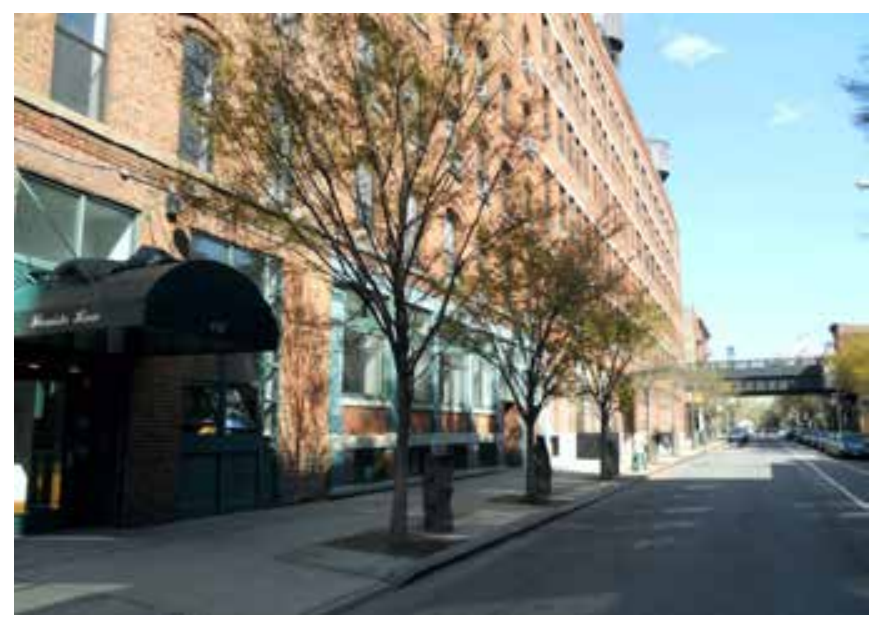

Resim 12. '7000 Meşe', Joseph Beuys, 1982.

Uluslararası Sanat Sergisi olan Dokumenta 7'de de (1982) Almanya- Kassel'i 7000 meşe ağacı ile yeniden ağaçlandırmayı planladı (Resim 11-12). Meşe ağaçları ha- yatın kırılganlığını ve doğa ile insan arasındaki karşılıklı ilişkiyi ifade etmekteydi. Herkes bir ağaca 210 Amerikan doları ödeyerek ağaç dikme eylemine katılabilmekteydi. Bunun karşılığında her katılımcı 'küçük meşe ağaçları büyüyor ve yaşam devam ediyor’ yazılı imzalı bir sertifika almaktaydı (Spaid, 2002).

Türkiye'de çevre sorunlarıyla ilgilenen ilk sanatçılardan biri olan Füsun Onur, 1978 yılında çevre kirliliğine karşı sert simgelerle yüklü bir nesneyle Türkiye Doğal Hayatı Koruma Derneği'nin sergisine katılır. Çimentodan bir kaidenin üzerindeki tel örgüden oluşturulmuş bir çit üzerindeki sülüklerin ve küçük çiçeklerin dizili olduğu bu çalışmasını çimentodan bir kaidenin üzerine yerleştirmiştir. Yine aynı kuruluşun bir sonraki yıl gerçekleştirdiği başka bir sergisi için sanatçı, dikkatini doğa mucizesinin neredeyse masalsı anlatımına yöneltmiştir (Brehm, 2007: 40-41). 'Bir Tohum Yeşeriyor' (Resim 13), toprakla doldurulmuş ve içinden stilize bir bitkinin filizlendiği, üstü açık, dikdörtgen bir cam kaptan oluşur. İzleyici, cama baktığında, toprağın altında hem bitkiye zarar verenlerin hem de bitkinin koruyucu meleğinin yer aldığı çeşitli oyuklar fark eder (Brehm, 2007: 41).

Sanatın sosyal bir olgu ve zamana göre değiş̧ebilen devinimli bir yapı olarak algılanmasıyla sanatçılar, sanatın iyileştirici gücüne inanmaya başladılar. Tanımını değiştirdikleri sanat aracılığıyla toplumsal bir dönüşüm yaratabileceğini düşünen her sanatçı bireye, topluma ve doğaya yönelik duyarlılı̆ını çeşitli yollarla ifade etti. Tüm bu çabalar insanoğlunun doğa üzerindeki geleceği hakkında düşünmesini ve konumunu sorgulamasını sağladı.

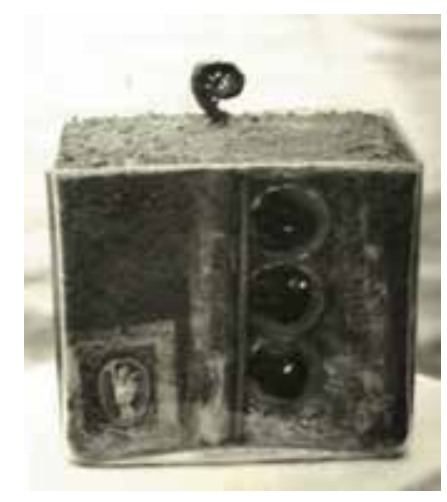

Resim 13. 'Bir Tohum Yeşeriyor', Füsun Onur, 1979. 


\section{Sonuç}

Kapsamı 1960 ve 1980 yılları arası dönem ile sınırlandırılan bu metinde ilk olarak değişen toplumsal değerlerin ve sanatsal pratiklerin, sanatçıların doğayı anlamlandırırken takındıkları bakış açılarında ne gibi değişikliklere yol açtığı incelenmiştir. Bu incelemede ilk olarak 1960'lı yıllardan önce doğanın sanatçılar tarafından nasıl algılandığı ve bunu yapıtlarında nasıl ifade ettikleri üzerinde durulmuştur. Buradan hareketle denilebilir ki, tarihsel olarak her çă̆ın sanatçıSI, kendisine ait bir doğa düşüncesine sahiptir ve bu düşünce alt yapısı ile birlikte doğaya karşı bir duruş sergilemiştir. Sanatçı bu duruş esnasında kimi zaman doğanın birebir taklidine dayalı gerçekçi çözümlemelerle kimi zaman duyguların daha yoğun işlendiği ve hatta daha gerçeküstücü ifadelerle kimi zaman da doğayı tamamen reddederek oluşturduğu düzenlemeleriyle yapıtına yön vermeye çalışmıştır. Ancak 60’ı yıllardan sonra doğa ve sanat arasındaki ilişkide eski çağlara göre daha farklı bir duruş sergilenmiş; düşünsel anlamda bir tür kopuş gözlemlenmiştir. Artık doğa sadece kendisinden feyz alınacak, öykünülecek veya reddedilecek dışarıdaki bir yapı olmaktan çıkmıştır. 1960 sonrası dönemde birçok sanatçının kendilerinden önceki çağların sanatçılardan farklı olarak, doğayı yalnızca dışarıdaki bir yapı olarak görmedikleri, doğanın süreçselliğini de içeren ve hatta bu sürece katılan ve onu var eden yapıtlar ürettikleri sonucuna varılmıştır. Sanatı yaşam sürecine katmak ve toplum ile sanat arasındaki bağları doğa üzerinden yeniden tanımlamak hedefiyle vücuda getirdikleri bu çalışmalarıyla da izleyici veya katılımcıların doğa üzerine yeniden düşünmelerini hedefledikleri saptanmıştır. Yalnızca dönemin çevreci hareketlerinden etkilenmedikleri aynı zamanda bu hareketlere ön ayak oldukları görülmüştür. Bu anlamda bu sanatçlar toplum, doğa ve sanat arasında kurulacak yeni ilişkilere yeni tanımlar kazandırmış, sanat ve yaşam arasındaki bağları pekiştirmişlerdir. Bunu da eserlerini uyguladıkları yeryüzünde insanlara yeni farkındalıklar sağlayıp, diğer canlılara da yeni yaşam alanları açarak gerçekleştirmişler ve insanoğlu olarak bu dünyada yalnız olmadığımıza, doğadaki yaşamın -tüm canlıları kapsayacak şekilde- kendisine dikkat çekmek istemişlerdir.

\section{Kaynakça}

Antmen, Ahu (2008). 20. Yüzyıl Batı Sanatında Akımlar, İstanbul: Sel Yay.

Bourrıaud, Nicolas (2005). Iliş̧kisel Estetik, çev. Saadet Özen, İstanbul: Bağlam Yayınları.

Brehm, Margrit (2007). Füsun Onur: Dikkatli Gözler lçin, çev. Barış Tut, İstanbul: YKY.

Celant, Germano (1992). “Arte Povera”. Art in Theory, Londra, Black well Publishing, s. 886-889

Read, Herbert (2004). “insani Sanat ve İnsanlık Dışı Doğa”, çev. Cemal i. Çakır, Sanat Dünyamız (92): 57-59.

Thornes, J. E. (1999). John Constable's Skies, Birmingham: Birmingham University Press.

Turhanl, Halil (2002). “Sanatta Devrimci Tufan”, Cumhuriyet Dergi (465): 9

Worrınger, Wilhelm (1995). Soyutlama ve Özdeşleyim, çev. İsmail Tunalı, İstanbul: Remzi Kitabevi.

Yıldız, Esra (2007). “iki Muhalifin Ardından”. Rh+ Sanat (42): 32-36.

Yılmaz, Mehmet (2006). Modernizmden Postmodernizme Sanat Ankara: Ütopya Yayınevi.

\section{Internet Kaynakları}

Greenberg, Clement (1939). “Avant-Garde And Kitsch”. Partisan Review, http://www.sharecom.ca/greenberg/kitsch.html (15.07.2012)

Kimmelman, Michael (1999). “Michael Heizer: A Sculptor's Colossus of the Desert" http://www.bebeyond.com/learnenglish/ dailyreadings/arts/desertsculptor.htm (23.12.2005)

Lipke, C.William (1969). “Fragments of a Conversation”, http://www. robertsmithson.com/essays/fragments.htm (4.11.2010)

Reynolds, Joshua (1768). "Seven Discourses on Art", The Project Gutenberg eBook, ed. Henry Morley (8 Mayıs 2009) http//www. gutenberg.org/files/-2176/2176-h/2176-h.htm (11.04.2014)

Sanford, Melissa (2004). “The Salt of Earth”, http//www. robertsmithson.com-/essays/sanford.htm (04.04.2010)

Spaid, Sue (2002). “Activism to Publicize Ecological İssues: Monitoring Ecological Problems", Ecovention: Current Art To Transform Ecologies, http://greenmuseum.org/c/ecovention/ sect2.html 02.05.2008) 


\section{Görsel Kaynaklar}

Resim 1. John Constable, Saman arabası, 1821 http://commons. wikimedia.org/wiki/File:John_Constable

Resim 2. Piet Mondrian, Kırmızı, Sarı ve Mavili Kompozisyon, 1921 https://www.pinterest.com/karus079/piet-mondrian/

Resim 3-4: Piero Manzoni, Dünyanın Kaidesi,1961 http://www.orbit. zkm.de/?q=node/6

Resim 5. Michael Heizer, Çift Negatif, 1969 http://doublenegative. tarasen.net/double_negative.html

Resim 6. Robert Smithson, Spiral Dalgakıran, 1970 http:// en.wikipedia.org/wiki/Spiral_Jetty

Resim 7. Jannis Kounellis, 11 At, 1969 http://www.artcritical. com/2010/11/21/kounellis/

Resim 8. Hans Haacke, Çim Büyür,1966-1969 http://greenmuseum. org/c/aen/Earth/Changing/artist.php

Resim 9. Hans Haacke, Ren Nehri Arındırma Projesi, 1972 http://www. vulgare.net/2008/12/hans-haacke-rhinewater

Resim 10. Joseph Beuys, Bataklık Eylemi, 1971 http://choreograph. net/articles/raw-thinking-a-body-moving

Resim 11. Joseph Beuys, 7000 Meşe, 1982 http://www.diaart.org/ sites/main/7000oaks

Resim 12. Joseph Beuys, 7000 Meşe, 1982 http://www.diaart.org/ sites/main/70000aks

Resim 13. Füsun Onur, Bir Tohum Yeşeriyor, 1979 Brehm, Margrit (2007). Füsun Onur: Dikkatli Gözler İçin, çev. Barış Tut, İstanbul: YKY. 